\title{
Epidural Hematoma: A Prospective Analysis of Morbidity and Mortality in 173 Patients
}

\section{Hematoma epidural: Uma análise prospectiva de morbidade e mortalidade em 173 pacientes}

\author{
1 Neurosurgeon, Hospital das Clínicas, Universidade de São Paulo, \\ School of Medicine (HC-FM-USP), São Paulo, SP, Brazil \\ 2 Neurosurgeon, Coordinator of Emergency Neurosurgery, HC-FM- \\ USP, São Paulo, SP, Brazil \\ 3 Physiatrist, Medical Institute of Orthopedics and Traumatology, HC \\ FM-USP, São Paulo, SP, Brazil \\ 4 Medical Intensivist, Head of the Department of the Neurological \\ Intensive Care Unit, HC-FM-USP, São Paulo, SP, Brazil \\ 5 Neurosurgeon, Professor, Universidade de São Paulo, School of \\ Medicine, São Paulo, SP, Brazil \\ 6 Neurosurgeon, Instituto do Câncer de São Paulo (São Paulo Cancer \\ Institute), São Paulo, SP, Brazil \\ ${ }^{7}$ Neurosurgeon, Professor, Department of Neurosurgery, HCFMUSP, \\ São Paulo, SP, Brazil
}

Jefferson Rosi Junior ${ }^{1}$ Almir Ferreira Andrade ${ }^{2}$ Lint chia Yeng ${ }^{3}$ Edwin Koterba ${ }^{4}$ Eberval Gadelha de Figueiredo ${ }^{5}$ Guilherme Lepski ${ }^{6}$ Manoel Jacobsen Teixeira ${ }^{7}$

Arq Bras Neurocir 2015;34:20-24.

Address for correspondence Jefferson Rosi Junior, MD, Rua Turiaçu 2237, ap 71 bloco B, São Paulo, CEP 05005001, Brazil

(e-mail: jefrosijr@gmail.com).

\section{Abstract \\ Keywords \\ - epidural hematoma \\ - craniotomy \\ - computed tomography \\ - intensive care units}

Objectives A few recent studies have focused on epidural hematomas (EDHs) that are routine in emergency rooms. The study was to evaluate the latest situation of affected patients by encephalic trauma associated with EDH in our service.

Methods Prospective study between September 1, 2003 and May 30, 2009. Data were computed regarding age, sex, trauma mechanism, qualification by Glasgow coma scale admission, presence of anisocoria, and evaluation by the recovery of Glasgow scale high, with all patients by computed tomography (CT) scan.

Results Among the 173 analyzed patients, mortality reached 20 patients (11.5\%). Mortality was higher in the subgroup of 76 patients (44\%) admitted with Glasgow coma scale (GCS $\leq 8$ ) with 17 deceased, corresponding to $85 \%$ of total deaths. Prevalence of male subjects (140 cases, $81 \%$ ) with bruises located in the temporal, frontal and parietal regions; 147 (85\%) patients underwent neurosurgical treatment by craniotomy. The worst prognosis was in patients with hematomas of higher-volume $(50 \mathrm{~mL})$, midline structures deviations greater than $1.5 \mathrm{~mm}$ and basal cisterns CSF closed. Conclusion The authors emphasize the correct indication of neurosurgery and the postoperative intensive care unit (ICU) as key factors for success in the treatment of patients with EDHs. received

April 1, 2014

accepted

November 1, 2014
DOI http://dx.doi.org/ $10.1055 / \mathrm{s}-0035-1547391$ ISSN 0103-5355.
Copyright $\odot 2015$ by Thieme Publicações License terms Ltda, Rio de Janeiro, Brazil

(c) $(1) \$$ 


\section{Resumo}

\section{Palavras-chave}

- hematoma epidural craniano

- traumatismos cranioencefálico

- tomografia computadorizada

- unidades de terapia intensiva
Objetivos Poucos estudos atuais tem focado os hematomas epidurais que são rotina nos serviços de emergência. $O$ estudo teve por objetivo avaliar a situação mais recente dos doentes acometidos por traumatismo crânio ancefálico associado a hematoma epidural no nosso serviço.

Métodos Estudo prospectivo entre 1 de setembro de 2003 a 30 de maio de 2009. Foram computados dados referentes a idade, sexo, mecanismo do traumatismo, qualificação pela escala de coma de Glasgoẁ a admissão, presença de anisocoria e avaliação pela escala de recuperação de Glasgow na alta, tendo todos os pacientes realizado tomografia de crânio.

Resultados Dentre os 173 pacientes analisados encontramos mortalidade de 20 pacientes (11,5\%). No subgrupo de 76 pacientes (44\%) admitidos em escala de coma de Glasgow (ECGLa) $\leq 8$ pontos, a mortalidade foi superior com 17 óbitos, correspondendo a $85 \%$ do total de óbitos. Prevaleceram indivíduos do sexo masculinos (140 casos, $81 \%$ ) com hematomas localizados na região temporal, seguido pelas regiões frontal e parietal; 147 (85\%) foram submetidos a tratamento neurocirúrgico por craniotomia. O prognóstico foi pior nos pacientes com hematomas de volume superior a $50 \mathrm{~mL}$, desvios de estruturas de linha mediana maiores que $1,5 \mathrm{~mm}$ e cisternas liquóricas basais fechadas.

Conclusões Os autores enfatizam a correta indicação da neurocirurgia e o pósoperatório na unidade de terapia intensiva como fatores chave para o bom resultado no tratamento dos doentes com hematomas epidurais.

\section{Introduction}

An epidural hematoma (EDH) is the abnormal collection of blood between the bone and the dura mater. ${ }^{1,2}$ Most EDHs occur in the skull as a direct result of traumatic brain injury (TBI), but in rare cases may also occur in the spinal cord. Nontraumatic causes for EDH include complications arising from punctures performed for epidural anesthesia and analgesia, or as result of craniotomy, craniectomy, laminotomy, or laminectomy. ${ }^{2-5}$

The site of bleeding may involve meningeal arteries, ruptured venous sinuses, or even fractured diploic bone, as in the case of primary EDHs. EDHs caused by postsurgical complications may also originate in the muscle, subcutaneous tissue, or skin, in cases where hemostasis is deficient, or when the patient has thrombocytopenia or coagulation deficits. ${ }^{2,5}$

\section{Materials and Methods}

We conducted a prospective study of 173 patients diagnosed with TBI-induced EDH who were monitored for their entire stay at the hospital, from September 1, 2003 to May 30, 2009. All patients were first evaluated by the emergency surgery team, who followed the ATLS (Advanced Trauma Life Support) standards of care. Afterward, they were seen by the emergency neurosurgery team and underwent a CT skull examination, which revealed the presence of a TBI-induced EDH in each case.

Patients whose hematomas were larger than $25 \mathrm{~cm}^{3}$ and located in the anterior or middle fossa, or were larger than 16 $\mathrm{cm}^{3}$ and were located in the posterior fossa, were operated immediately. This study was approved by the University of São Paulo's ethics in research committee, under number 0120/08.

\section{Results}

Of the 1,017 TBI patients admitted to the hospital, 173 ( $n=173,17 \%$, mean age $=30$ years $)$ were diagnosed with an EDH. Of these, $147(n=147,85 \%)$ underwent surgery. Among the 147 patients who underwent surgery, 145 received a conventional craniotomy, whereas the remaining 2 underwent embolization.

Most patients were male ( $n=140,81 \%)$, and there were also 19 children (11\%) in our series. The youngest patient was 1 year old at the time of admission and the oldest was 82 .

Seventy-six (44\%) patients had TBI-induced coma (GCS score $\leq 8$ ) and 17 of these patients passed away, accounting for $85 \%$ of all deaths. Another 97 patients (56\%) were admitted to the ER with a GCS score of $\geq 9$. Among these patients, there were three deaths, $15 \%$ of all deaths. Thirty-nine ( $n=39,22.5 \%)$ of these patients had a GCS score of 15 points, and no deaths were reported in this group.

Eighteen patients (10.4\%) had anisocoria upon admission, and there were six (33.3\%) deaths among these patients.

- Table 1 lists the brain regions affected by EHD. - Table 2 illustrates the midline shift (MS) of certain brain structures and the associated mortality. - Table 3 lists EDH volume and its correlation with mortality. -Table 4 lists additional intracranial lesions outside the EDH. - Table 5 shows that the TBI affected other organs away from the EDH. - Table 6 illustrates the types of TBI that led to the formation of EDH. 
22 Epidural Hematoma Rosi Jr. et al.

Table 1 Brain regions most frequently affected with epidural hematomas

\begin{tabular}{|l|l|l|l|l|l|}
\hline Region & Frontal & Temporal & Parietal & Occipital & Posterior fossa \\
\hline Patients & 62 & 108 & 39 & 10 & 06 \\
\hline$\%$ & 27.6 & 48.0 & 17.4 & 4.4 & 6.0 \\
\hline
\end{tabular}

Three patients (1.7\%) had an EDH in the posterior fossa that was larger than $16 \mathrm{~cm}^{3}$, whereas another three patients had an EDH in the posterior fossa that was smaller than 16 $\mathrm{cm}^{3}$. Death was reported in 20 patients (11.5\%), and - Table 7 highlights the correlation between death and patients' age, GCS score upon admission, cause of TBI, presence of anisocoria, hematoma volume, MS, and patency of the basal cisterns. - Table 7 also shows the link between the EDH and other intra- and extracranial lesions.

\section{Discussion}

Male patients, especially young ones, are significantly more likely than female patients to be affected by TBIs and subse-

Table 2 MS of brain structures caused by supratentorial EDHs

\begin{tabular}{|l|l|l|l|l|}
\hline MS (mm) & I 0-0.5 & II 5.4-6.8 & III 6.9-1.2 & IV >1.5 \\
\hline Patients & 135 & 14 & 14 & 10 \\
\hline$\%$ & 78 & 8.1 & 8.1 & 5.8 \\
\hline Death & 13 & 02 & 02 & 03 \\
\hline \% deaths & 9.6 & 14.2 & 14.2 & 30 \\
\hline
\end{tabular}

Abbreviations: EDH, epidural hematomas; MS, midline shift of brain structures.

Table 3 Volume of supratentorial EDHs

\begin{tabular}{|l|l|l|l|}
\hline Volume $(\mathbf{m L})$ & $<\mathbf{3 0}$ & $\mathbf{3 0 - 5 0}$ & $>\mathbf{5 0}$ \\
\hline Patients & 131 & 29 & 13 \\
\hline$\%$ & 75.8 & 16.7 & 7.5 \\
\hline Death & 09 & 07 & 04 \\
\hline \% deaths & 6.8 & 24.1 & 30.7 \\
\hline
\end{tabular}

Abbreviation: EDHs, epidural hematomas.

Table 4 Intracranial lesions associated with EDH

\begin{tabular}{|l|l|l|}
\hline Injury & Patients & $\%$ \\
\hline Skull fracture & 150 & 86.7 \\
\hline Meningeal hemorrhage & 70 & 40.4 \\
\hline Pneumocranium & 50 & 28.9 \\
\hline Brain contusion & 34 & 19.6 \\
\hline Subdural hematoma & 12 & 6.9 \\
\hline Diffuse axonal injury & 04 & 2.3 \\
\hline
\end{tabular}

Abbreviation: $\mathrm{EDH}$, epidural hematoma. quent EDHs. This is consistent with several neurotraumatology reports, which suggest that males are more likely to engage in behaviors that would lead to such consequences, both at work and in leisure or sports activities. ${ }^{5}$

In our study, the most common causes of EDH were traffic accidents, followed by falls from heights, as has been reported in previous studies (-Table 6 ). No one cause of TBI

Table 5 Lesions in other organs associated with EDH

\begin{tabular}{|l|l|l|}
\hline Organs & Patients & $\%$ \\
\hline Facial fracture & 13 & 7.5 \\
\hline Spinal fracture & 17 & 9.8 \\
\hline Lower limb fracture & 7.5 & 13 \\
\hline Pulmonary contusion & 12 & 6.9 \\
\hline Rib fracture & 08 & 4.6 \\
\hline Pneumothorax & 07 & 4.0 \\
\hline Spleen injury & 04 & 2.3 \\
\hline Upper limb fracture & 04 & 2.3 \\
\hline Hip fracture & 03 & 1.7 \\
\hline Clavicle fracture & 03 & 1.7 \\
\hline Stomach injury & 01 & 0.5 \\
\hline Liver/kidney & 01 & 0.5 \\
\hline
\end{tabular}

Abbreviation: EDH, epidural hematoma.

Table 6 Type of TBI leading to the EDH

\begin{tabular}{|l|l|l|}
\hline TBI & Patients & $\%$ \\
\hline Being run over & 40 & 23.2 \\
\hline Motorcycle accident & 29 & 16.8 \\
\hline Auto collision & 12 & 7.0 \\
\hline Bicycle collision & 07 & 4.0 \\
\hline Falling out of moving car & 04 & 2.3 \\
\hline Total traffic accidents & 92 & \\
\hline Fall from height & 32 & 18.5 \\
\hline Regular fall & 12 & 7.0 \\
\hline Fall from stairs & 09 & 5.2 \\
\hline Total falls & 53 & \\
\hline Unknown & 17 & 9.8 \\
\hline Struck by object & 03 & 1.7 \\
\hline Aggression & 08 & 4.6 \\
\hline
\end{tabular}

Abbreviations: EDH, epidural hematoma; TBI, traumatic brain injury. 
Table 7 Detailed analysis of deceased patients

\begin{tabular}{|c|c|c|c|c|c|c|c|c|c|}
\hline HR & age & mec & gl & Ani & Vol & SMS & VC & As sn & A ot \\
\hline $2884795 i$ & 42 & run & 06 & Yes & $30-50$ & I & dec & dai/sh & $\mathrm{ff}$ \\
\hline $13745636 d$ & 21 & $? ? ?$ & 07 & No & $>50$ & IV & dec & & \\
\hline $13769926 \mathrm{~g}$ & 16 & Auto $\mathrm{C}$ & 06 & No & $30-50$ & I & dec & sh & \\
\hline $13821395 b$ & 30 & ??? & 03 & Yes & $>50$ & IV & dec & & \\
\hline $13802854 b$ & 30 & foh & 03 & No & $<30$ & I & dec & edm & \\
\hline $13829300 \mathrm{e}$ & 31 & Moto a & 04 & Yes & $>50$ & I & dec & $\operatorname{csf}$ & lung \\
\hline $13754028 f$ & 14 & $\mathrm{fcm}$ & 06 & Yes & $30-50$ & II & dec & & \\
\hline $13720756 i$ & 36 & ffh & 08 & No & $<30$ & I & dec & cont & spleen/kidney \\
\hline و13736431 & 09 & aggres & 10 & No & $<30$ & I & dec & cont/sh & \\
\hline $13735218 \mathrm{~h}$ & 23 & $? ? ?$ & 12 & No & $30-50$ & II & dec & & \\
\hline 13795067j & 42 & ffh & 03 & No & $30-50$ & III & dec & & \\
\hline 13752619 e & 20 & Moto a & 06 & Yes & $<30$ & I & dec & sh & \\
\hline 2689045h & 46 & run & 03 & Yes & $30-50$ & III & dec & & \\
\hline $13789683 c$ & 72 & run & 14 & No & $<30$ & I & $\mathrm{nl}$ & cont & $\mathrm{ff}$ \\
\hline و13766257 & 19 & Moto a & 07 & No & $<30$ & I & dec & sh & \\
\hline $13801293 i$ & 30 & aggres & 03 & No & $>50$ & IV & $\mathrm{dec}$ & & \\
\hline $13760273 b$ & 30 & Moto a & 06 & No & $<30$ & I & dec & sh/dai & ff/lung \\
\hline $13785554 b$ & 82 & ffh & 07 & No & $<30$ & I & $\mathrm{nl}$ & sh/cont & \\
\hline $13779124 b$ & 59 & run & 06 & No & $30-50$ & I & dec & sh/cont & \\
\hline 13823207j & 64 & run & 06 & No & $<30$ & I & $\mathrm{nl}$ & cont & $\mathrm{ff}$ \\
\hline
\end{tabular}

Abbreviations: ???, unknown mechanism; A ot, other systemic injuries related to the EDH; age, age in years; aggres, aggression; Ani, Anisocoria; As sn, other intracranial lesions caused by the EDH; Auto c, auto collision; ce, cerebral edema; Cont, cerebral contusion; csf, CSF leak; dai, diffuse axonal injury; dec, decreased; dec, decreased; EH, epidural hematoma; ff, facial fracture; ffh, fall from height; foh, regular fall; gl, Glasgow Coma scale score upon admission to emergency room; HR, hospital record; hsd, subdural hematoma; MD, midline deviation; mec, mechanism of TBI; Moto a, motorcyle accident; MS, midline shift of brain structures; mvd, moving vehicle drop; $\mathrm{nl}$, normal; OC, other changes; pulm, pulmonary contusion; run, being run over; s, swelling; sh, subarachnoid hemorrhage; she, subdural hematoma; typ, type of TBI; VC, state of the ventricles and cisterns tomography; Vol, hematoma volume.

was more significantly associated with mortality. It seems clear that some ways of preventing many traumatic events would be to improve society's behavior with regards to traffic laws, provide adequate public roads, provide workers with better equipment to increase their safety on the job, and to provide ways of better protecting children from domestic accidents. $^{5}$

- Table 5 lists patients' lesions in organs other than the brain. This highlights the importance of the initial care provided to these patients upon admission to the emergency room, not only from the neurosurgeon/neurotraumatologist but also from specialists in general surgery and traumatology. One should not only evaluate the patient from a neurologic standpoint; he/she must first be assessed for the other ATLS parameters to prevent potentially fatal complications related to breathing, bleeding, or hemodynamic problems that may lead to additional complications prior to or during treatment by the neurosurgeon. 2,4,6

Large EDHs should be operated on, regardless of their location. Smaller hematomas should also be operated on if they are located in the posterior or middle fossa, as these EDHs carry a risk of compressing or causing irreversible damage to the brain stem. These cases are mostly treated promptly via craniotomy. There is strong evidence that a delay in excising the EDH may compromise prognosis, especially when the patient has a high GCS score upon admission $(13,14$, or 15$)$. It has often been observed that patients without any other associated serious intracranial or systemic lesions have a good prognosis. ${ }^{5,7}$

The main cause of TBI-induced EDH is rupture of the meningeal arteries, especially the middle meningeal artery, which can lead to the formation of large temporal hematomas. These may also extend to the frontal and parietal lobes, creating a neurosurgical emergency. ${ }^{2,6-8}$

de Andrade et $\mathrm{al}^{1}$ described an alternative treatment for small EDHs (also known as laminar hematomas) that do not exert pressure on the central nervous system. This method consists of the embolization of posttraumatic pseudoaneurysms or posttraumatic arteriovenous fistulas once they are identified with digital angiography. If angiography is not available, patients should undergo a classic craniotomy to remove the $\mathrm{EDH}$, as it may in fact be blocking the TBI-induced vascular injury, and one of these lesions may begin to bleed later on, once the patient is out of the hospital and the hematoma has been absorbed. If angiography is performed and vascular lesions are not identified, the craniotomy is not 
performed and the patient may be discharged and receive outpatient care. In the current group of patients, those with laminar EDHs did not undergo surgery. $3,8,9$

Additional causes of EDH (other than lesions to the meningeal arteries) are bleeding from the diploe and from ruptured intracranial venous sinuses. Skull fractures, which cause bleeding of the diploe, often also cause meningeal vascular injuries and bleeding of the sinuses, when vascular structures are perforated.

Previous work has shown that skull fractures occur along with EDH in approximately $90 \%$ of cases and are generally immediately adjacent to them. In the current group of patients, fractures occurred in $86.7 \%$ of EDHs. In fact, fractures were the most common feature associated with EDH, followed by traumatic subarachnoid hemorrhage (TSH) and other intracranial lesions listed in $\mathbf{- T a b l e ~} 4$. There is also the remote possibility that an EDH from fractured diploe could continue to grow slowly and reach a size large enough to cause symptoms. This does not occur in the embolization procedure for meningeal vascular lesions described previously. In this type of situation, the need for neurosurgery arises via conventional craniotomy, even for patients without traumatic meningeal vascular lesions. Whenever the risks associated with anesthesia or possible infection are thought to outweigh the benefits of excising the small EDH, the best option for these patients is to discharge them and have them return to the office for follow-up care. Another option is to perform the excision approximately 30 days later in asymptomatic patients, or before, if the patient becomes symptomatic., 1,2,10-14

Note that the diffuse axonal injury reported in - Table 4 refers to patients' indirect CT findings, such as Marshall-type II diffuse injury, i.e., tiny foci of subcortical hemorrhage in the brainstem, cerebellum, or in the deep white matter of the cerebral hemispheres, caused by the rupture of tiny vessels along the axonal tracts. If MRI had been available, it is likely that the number of cases diagnosed with diffuse axonal injuries would be considerably greater.

Our data also support the classic finding in the literature that EDHs occur most commonly in temporal regions, followed by the frontal and parietal lobes; the least common areas for EDHs are the occipital lobe and posterior fossa (-Table 1).

The mortality rates in the current group of patients are also in line with the literature. The information in - Tables 2 and 3 confirms that larger EDHs (especially those $>50 \mathrm{~mL}$ ), as well as EDHs with larger MSs are associated with significantly higher mortality rates than smaller EDHs with smaller MSs.

Patients with small EDHs have a relatively good prognosis on the rehabilitation scale, as long as they receive postoperative treatment in the ICU. Patients whose postoperative treatment is conducted outside the ICU usually have a poorer prognosis.

Treatment in the ICU is especially recommended for patients such as those listed in - Tables 2, $\mathbf{3}$ and 7, who are admitted in a state of coma, with possible anisocoria and large EDHs, all conditions that lead to reduced basal cisterns and large MSs. These patients are more likely to suffer from secondary cerebral ischemic lesions due to the pressure exerted by the EDH on the brainstem, as well as from hypoxia and further complications caused by long stays in the ICU. All of these factors clearly contribute to this group of patients' higher mortality rates. ${ }^{1,9-14}$

\section{Conclusion}

Mortality among patients affected by TBI-induced EDH is significantly higher in patients admitted to the emergency room in a coma, and the presence of anisocoria is an unfavorable prognostic marker.

Other unfavorable markers include large hematomas, the degree MS (with the accompanying distortion of other brain structures), and a reduction in the ventricles and basal cisterns. Craniotomy together with EDH excision is the main treatment of choice, and its indication and postoperative treatment in the ICU are directly correlated with a favorable prognosis.

\section{Conflicts of Interest}

The authors declare no conflict of interest.

\section{References}

1 de Andrade AF, Figueiredo EG, Caldas JG, et al. Intracranial vascular lesions associated with small epidural hematomas. Neurosurgery 2008;62(2):416-420, discussion 420-421

2 Andrade AF, Paiva WS, Soares MS, De Amorim RL, Tavares WM, Teixeira MJ. Classification and management of mild head trauma. Int J Gen Med 2011;4:175-179

3 Magalhães E, Govêia CS, Ladeira LC, Queiroz LE. [Hematoma after epidural anesthesia: conservative treatment. Case report.]. Rev Bras Anestesiol 2007;57(2):182-187

4 Pereira CU, Barbosa MB, Machado JC, Machado SC. Hematoma extradural bilateral causado por ruptura do seio sagital superior. Considerações sobre 2 casos. Arq Bras Neurocir. 2000;19(2):103-105

5 Radulovic D, Janosevic V, Djurovic B, Slavik E. Traumatic delayed epidural hematoma. Zentralbl Neurochir 2006;67(2):76-80

6 Coimbra CJ, Azevedo Filho HR, Furtado GJ, Lima FT. Hematoma extradural: considerações sobre 66 caso. Arq Bras Neurocir. 1983; 2(2):113-123

7 Ciquini Júnior O, Dos Santos AL, Manreza LA, Plese JP, Marino Júnior R. Traumatic extradural hematoma in childhood and normal early computed tomography: report of 2 cases [in Portuguese]. Arq Neuropsiquiatr 1992;50(3):361-364

8 Mello LR, Furg FP, Braga FM. Hematoma extradural: estudo comparativo entre pacientes em coma e não. Arq Bras Neurocir. 1991;10(2):57-77

9 Pereira CU, Leão JDBC, Silva AD, Duarte GC. Hematoma extradural na infância. Arq Bras Neurocir. 2001;20(4):101-105

10 Cheung PS, Lam JM, Yeung JH, Graham CA, Rainer TH. Outcome of traumatic extradural haematoma in Hong Kong. Injury 2007; 38(1):76-80

11 Melro CA, Araújo JF, Oliveria MA, Balbo RJ. False aneurysm of the median meningeal artery: the importance of angiographic diagnosis. A case report [Portuguese]. Arq Neuropsiquiatr 1993;51(3):403-406

12 Rosa A, Salomón E. Hematomas epidurales en ninõs. Neuroeje. 2000;14(2):76-83

13 Rosi Júnior J. Neurônio perguntas e respostas em neurocirurgia. São Paulo, Brazil: Editora Scortecci; 2011

14 Rosi Júnior J. Hematoma epidural: análise prospectiva de 73 doentes operados pelo autor. RFML 2008;13(5):249-253 